DOI 10.14746/ssp.2020.3.7

Serhii DANYLENKO

Taras Shevchenko National University of Kyiv

ORCID: 0000-0003-3873-2525

Sofiia SHUSTENKO

Taras Shevchenko National University of Kyiv

ORCID: 0000-0001-5815-7236

\title{
Activities of the Council of Europe in ensuring the human right to information: issues of compliance with the modern challenges of democracy
}

\begin{abstract}
In the article, the authors review and systematize the activities of the Council of Europe in ensuring one of the key factors of liberal democracy - freedom of expression, which is a prerequisite for the implementation of a number of other rights and freedoms. The authors categorize the basic documents, both those that have already become classics and those adopted recently, where this phenomenon has found legal consolidation. It studies the way in which it affects the formation and development of the human right to information in Europe. Attention is drawn to the fact that, with the emergence of new ways of disseminating information, including the potential of the internet first and foremost, the accumulation of information and the European community's efforts to protect this fundamental democratic right, its further strengthening remains urgent. The Council of Europe has lost control over the observance of the human right to information, and information is used with destructive intent, which poses a danger to one of the fundamental values on the basis of which European society operates today, and raises the risk of the restoration of authoritarianism. First and foremost, there is a threat of authoritarianism in the new democracies of Eastern Europe. The global COVID-19 pandemic and the recession of the world economy, which encourages citizens to choose authoritarian leaders, may be the trigger for slipping into authoritarianism.
\end{abstract}

Key words: Council of Europe, human right to information, media, stereotypes, disinformation, content control, access to information

\section{Identifying the issue and its relevance}

The issue of the protection of the human right to information by the Council of Europe in an era of global political transformation, to- 
gether with the information and communication revolution has become increasingly important and relevant. In the context of the transformation of the modern international relations system and formation of a new world order, the main task of the Council of Europe is to coordinate the legislation of member states to ensure that the norms of liberal democracy have been set out in the European Convention on Human Rights enacted in 1950, and the Convention for the Protection of Human Rights and Fundamental Freedoms dated 1953.

\section{Analysis of the latest research and publications}

Research into the Council of Europe's policy on the protection of the human right to information found reflection in some works of the Ukrainian and foreign academics. Thus, Leonid Huberskyi specified some aspects of the legal activity of the Council of Europe which is determinative in the development of European legislation and is directed toward the harmonization and improvement of the legal systems of member states on the basis of general standards; Eugenia Makarenko systematized the concepts of the information policy of the Council of Europe and the European Union from 1994 to 2002 in her monograph International Information Relations; O. Kuznetsova, G. Pocheptsov, and O. Skakun thoroughly explored the topic of the Council of Europe and the information policy formation of related international organizations in their studies.

Maeve McDonagh, professor of law from University College Cork in Ireland explores the conceptual basis for the recognition of the right to information. She has highlighted the role of the right to freedom of expression in furthering the recognition of the right to information and also explored the engagement of other rights in such recognition. Rachel Hanna, legal researcher and campaigner at Access Info, explores practices that will help governments globally to strike the right balance between transparency and privacy in an effective way, in the public interest. She has suggested introducing risk impact assessments for all Covid19-related data collection efforts. Professor Sionaidh Douglas-Scott from Queen Mary University of London explores the role of EU institutions in protecting the human right to information, especially the normative and doctrinal framework for the protection of human rights in the EU.

The aim of the article is to explore the traditional directions of the political and legal activities of the Council of Europe in terms of ensuring 
the human right to information, and also the conformity of the Council of Europe's actions in the information sphere to the current challenges facing European democracy as a result of the COVID-19 pandemic and related information, as well as the ambiguous role of the internet as a dissemination channel.

\section{Presentation of the main research material}

It should be noted that the mass media play one of the leading roles in the protection of the human right to information. Strengthening of the mass media's power, in particular the internet, promotes awareness, engagement, and extension of access to information. However, we should be aware of the danger of certain threats and challenges which can appear in the information era in front of a person, society, or state. "The mass media strengthen sympathy and global activity in the sphere of human rights, but at the same time there is a threat of hatred, stereotypes and misinformation. Children and youths are especially vulnerable to online risks" (The Council of Europe, 2019).

One of the human rights most closely linked to the mass media is probably the right to freedom of opinion and expression. Freedom of expression, as affirmed in human rights instruments, encompasses the right to receive and disseminate information, the right to silence, the right to form own opinions (for instance, the right to choose one's own clothes, headwear, music, literature, or movies). It covers artistic expression, political and commercial language, academic freedom and the right to freedom of speech of journalists. This spectrum suggests how important this right is for people, enabling them to achieve personal fulfillment and dignity or to find purpose in life, and promote the development of individuality. This freedom is also important for communities and social units created to achieve progress, to promote equality, democracy, and self-government. Freedom of expression of thought is important in itself, and is a prerequisite for the implementation of a number of other rights and freedoms (The Council of Europe, 2019).

In the context of the topic we have chosen, we consider it necessary to examine the concept of the human right to information. O. Yaremenko, a Ukrainian researcher, specifies the human right to information as a group of fundamental human rights which determine personal social standing in the system of information relations. In their turn, informa- 
tion relations can be considered as relations that arise in all spheres of life and activity of the society or the state during information reception, usage, distribution, storage, processing, or protection (Yaremenko, 2002, p. 157). Meanwhile, we shall understand the category of fundamental human rights as the legal possibilities essential for personal existence and development, and which need to be recognized as integral and general and equal for all, and provided and protected by the state according to international standards (Tsvik, Petryshyn, Avramenko, 2009, p. 447).

A key stage in providing the human right to information is the adoption of the Declaration on mass communication media and Human Rights by the Council of Europe on January 23, 1970. The Declaration, among other things, emphasizes that the mass media play an important role for the public. The document notes that the mass media are subject to the right to freedom of expression, which includes the freedom to disseminate information. Nation states have a reasonable obligation to provide information on matters of public interest, while the mass media have a duty to provide complete and comprehensive information on public affairs. The independence of the press and other media from state control is separately underlined, whereas the restriction of this independence is permitted only by court decision, not by the executive branch. Direct or indirect censorship in the media is also prohibited (Parliamentary Assembly of the Council of Europe, 1970).

According to the Declaration on mass communication media and $\mathrm{Hu}-$ man Rights, the independence of the media must be protected from the threat of monopolies. Neither private enterprises nor financial groups should be entitled to a monopoly in the field of press, radio or television, nor should a monopoly controlled by the government be allowed to emerge. Individuals, social groups, regional or local authorities should be entitled to be engaged in this activity as long as they adhere to established licensing rules. Special measures should be taken to ensure the freedom of foreign journalists, including the staff of international news agencies, in order to enable the public to obtain accurate information from abroad. These measures should cover the status, duties and privileges of foreign journalists and include protection against arbitrary deportation. In turn, they should provide appropriate obligations for foreign journalists to accurately cover events (Parliamentary Assembly of the Council of Europe, 1970).

It is worth noting that the document includes measures to protect the individual from any infringement of the right to respect for privacy. The 
right to respect for privacy is primarily the right to lead one's life at one's discretion with minimal outside interference. The convention emphasizes that attempts to obtain information through modern technical devices (observation devices, secret microphones, computers, etc.), harming the right to respect for privacy, may become highly problematic. In cases where regional, national or international computer databanks are set up, the individual should not completely lose protection from invasion of personal privacy through the gathering of information that could be relevant to personal privacy. Databanks should be limited to the necessary minimum of information required for tax purposes, pension schemes, social security schemes, or similar issues (Parliamentary Assembly of the Council of Europe, 1970). It is important to state that, at that time, such a phenomenon as social networking had not yet been created (which would be used not only as a means of communication, but more so as a tool of influence and micro-targeting for political and marketing purposes).

Governments of nation states have always been trying to maintain certain levels of control over the media and access to the media in order to influence the masses and gain their support, or stop the opposition from taking certain actions. However, a highly controlled media reduce social awareness, knowledge of global events, reliable analysis, and information about the state of the economy, political events, or social facts. State control of the media can be performed in a very purposeful manner such as, for example, scanning internet traffic or telephone conversations for the purposes of national security. In other cases, governments try to completely deny access to specific information. This was evidenced by later events such as the closure of the mobile network in Iran in mid-2009, and in Egypt in late 2010, the muting of radio stations, satellite television, or the expulsion of journalists from conflict zones. For example, in 2009, journalists were ordered to leave the northwestern province of Xingjiang in China, in order to diminish media coverage of ethnic violence in the region (The Council of Europe, 2019).

Media control executed by governments is a concern in Europe. For example, in 2011, Hungary adopted a media law that authorized a public body to monitor all media (including private content providers), impose fines, and terminate or close the media on the basis of certain unclear principles. In a number of other European countries, alleged defamation is still a ground for criminal prosecution.

Journalists can be sent to prison if they publish or state facts or thoughts which might offend someone. In decisions connected with cases 
of defamation, the European Court of Human Rights has repeatedly stated that prison sentences for press representatives contradict the right to freedom of speech of journalists and are violations of fundamental human rights, although cases of hate speech, expressed aggression or appeals to violence, should be treated as an exception. The European Court of $\mathrm{Hu}-$ man Rights has made considerable efforts to consolidate the framework principles concerning freedom of expression in accordance with Article 10(2) of Vienna Declaration on Human Rights. The Court adjudged that this right is "one of the main prerequisites for the establishment of a democratic society" (The Council of Europe, 2019).

Governments, including democracies, tend to use various pretexts to control the media as much as possible. One of those reasons was the COVID-19 pandemic in 2020. Threats to freedom of information during the pandemic have been reported in Albania, Armenia, Azerbaijan, Bosnia and Herzegovina, Croatia, Greece, Hungary, Italy, Kosovo, Moldova, Poland, Romania, Russia, Serbia, Slovenia, Spain, Turkey, Ukraine and the United Kingdom (European Federation of Journalists, 2020).

Some governments in member states of the Council of Europe have opportunistically taken advantage of emergency coronavirus legislation to push through restrictions which erode press freedom. While some of these measures have threatened press freedom unintentionally, others have been implemented knowingly. While some curbs on rights may be necessary to combat the pandemic, those limiting media freedom are excessive. Most concerning, while some of the restrictions due to the coronavirus will be temporary, others risk being extended long after the health crisis is over ( 52 press freedom cases documented in CoE Member States during pandemic, 2020).

Zselyke Csaky, director of European and Eurasian studies at the Freedom House non-governmental organization, notes not only the deterioration of the situation in the field of freedom of speech around the world, but also that this process has affected democracies. Now, many Hungarian politicians, especially from right-wing and populist parties, express contempt for the media and sharply criticize journalists, which also undermines people's confidence in the press, the expert notes.

She said that over the past five years, they have observed a general decline in confidence in most institutions of liberal democracy, including the press (Galperovich, Jegisman, 2019).

The leaders of the Council of Europe indicate a hidden danger to freedom of the media, and by extension to the human right to information. 
The Council of Europe Commissioner for Human Rights, Dunja Mijatovic has noted that if there was an immediate lesson to learn from the COVID-19 pandemic, it was that free and quality journalism is a crucial asset of democracy - and a threat to authoritarian leaders. While countries around the world were introducing lockdowns and very severe restrictions to people's liberty, journalists and media professionals were staying out to keep us informed (DW freedom, 2020).

Her position is shared by international experts on freedom of expression. The United Nations Special Rapporteur on the promotion and protection of the right to freedom of opinion and expression, the OSCE Representative on Freedom of the Media and the IACHR Special Rapporteur for Freedom of Expression released a joint statement on the importance of access to information during the COVID-19 pandemic on March 19, 2020. The statement notes that "broad restrictions on access to the internet cannot be justified on public order or national security grounds" and urges "all governments to robustly implement their freedom of information laws to ensure that all individuals, especially journalists, have access to information" (European Federation of Journalists, 2020).

The Vienna Declaration of June 25, 1993 played an important role in the development of the human right to information. It emphasizes, among other things, that the Council of Europe is the "the pre-eminent European political institution capable of welcoming, on an equal footing and permanent structures, the democracies of Europe freed from communist oppression. For that reason, the accession of those countries to the Council of Europe is a central factor in the process of European construction" based on pan-European values. Such accession is provided, given that "the applicant country has brought its institutions and legal system into line with the basic principles of democracy, the rule of law, and respect for human rights. The people's representatives must have been chosen by means of free and fair elections based on universal suffrage. Guaranteed freedom of expression and notably of the media, protection of national minorities and observance of the principles of international law must remain $[\ldots]$ decisive criteria for assessing any application for membership. An undertaking to sign the European Convention on Human Rights and accept the Convention's supervisory machinery in its entirety within a short period of time is also fundamental" (Vienna Declaration, 1993).

Within the Vienna Declaration dated October 9, 1993, an important place is dedicated to the reform of the control mechanism for compliance with the European Convention on Human Rights. "With the Euro- 
pean Convention for the Protection of Human Rights and Fundamental Freedoms which entered into force 40 years ago the Council of Europe created an international system for the protection of human rights which is unique of its kind. Its main distinguishing feature is that contracting States assume the obligation to effectively protect the human rights enshrined in the Convention and to accept international monitoring in this respect. This responsibility has been so far carried out by the European Commission of Human Rights and the European Court of Human Rights" (Vienna Declaration, 1993).

One of the most important components of protecting the human right to information in the 21 st century is the internet. To date, the Council of Europe consists of 47 member states, representatives of the private sector, civil society and other bodies working hard in order to build an internet based on human rights, democracy, and the supremacy of law. The Council of Europe is trying to turn the internet into a safe and open environment where freedom of expression, freedom of assembly, respect for privacy, diversity, culture, education, and learning can flourish. In the furtherance of this goal, the Council of Europe has developed a number of international conventions in the areas of cybercrime, personal data protection, and child protection. It has also been developing general legislation, in the form of recommendations to member states and guidelines for internet private sector bodies. The European Convention on Human Rights is the most important framework for protection of human rights on the internet. The European Court of Human Rights, which passes resolutions on applications for Convention violations, has already issued significant enactments in the field of online environment, right to freedom of expression, access to information, and right to respect for privacy (The Council of Europe, 2019).

The internet as a factor of civil society development should be considered a tool for political emancipation, as well as a means of disseminating information and thoughts on a global scale, that can be used by journalists, human rights defenders, and opposition movements. In all international forums, and through cooperation between member states of the Council of Europe, issues of development and protection of freedom of speech and convictions, as well as freedom of assembly and of association, both on the internet and in real life, are discussed within the framework of adherence to other fundamental human rights. During global summits on the issue of the information society, governments of the majority of states have confirmed their unconditional acceptance of the General declaration 
of human rights within the internet. In return, the Human Rights Council at the United Nations has constantly emphasized the importance of the protection of fundamental human rights and free movement of information in an online environment (France Diplomacy, 2019).

However, a great number of countries cannot guarantee freedom of speech on the internet. One in three users in the world does not have access to free and unlimited internet. France (being a prominent state of the Council of Europe), for example, condemns censorship and restriction of access to the internet, both private and general, in direct (through obstruction, blocking of internet resources or unjustified filtering) or indirect form - under pretense of protection from blasphemy, cybercrime, and terrorism. Intellectual property rights are crucial for creative and innovative activities. At the same time, the digital revolution contributes to a fundamental transformation in the consumption of cultural goods and, consequently, the transformation of the economic models that provide the income of artists. The prosperity of a dynamic and creative digital economy is impossible without a firm commitment to the protection of intellectual property rights (France Diplomacy, 2019).

Effective protection of personal data and privacy on the internet is paramount for building user confidence and security. Therefore, it is essential to prevent actions that constitute violations of the right to respect for privacy (illegal possession of personal data, misuse or unauthorized distribution of personal data, and the like) so that users are able to control their personal data, and this basic right could be preserved by all intermediaries (France Diplomacy, 2019).

The internet is a driver of economic growth and a vector of freedom and democracy. But it is also a space where pirates, criminal elements, and even states that finance terrorism can operate freely and with impunity. Types of threats evolve rapidly, and now include cyberespionage, damage to networks and services, or physical destruction through virtual attack. From now on, any country, its vital infrastructure, banks, and even the entire economy could be paralyzed by a computer attack - such as the attack of the Petya virus, which struck the Ukrainian government and corporate institutions on June 27, 2017. To emphasize the damage done to the media, broadcasts were stopped by UA:First and TRC Kyiv TV channels. It is completely natural that the double nature of virtual space has induced states to increase vigilance, improve protection of government information systems and vital infrastructure, and even develop some illicit means. States have also been forced to consider possible legal recourse to limit the risks 
connected with the internet. In the sphere of international relations, cyberspace has special diplomatic importance, due to the matter of ensuring the stability and security of the internet (France Diplomacy, 2019).

The stances of international organizations' member states on the strengthening of cyberspace security differ considerably. Some consider it necessary to develop a binding international legal instrument to regulate the actions of states; on the contrary, others believe that states are not the only stakeholders and solutions to improve internet security should be developed in conjunction with the corporate sector and civil society. They contend that increased state control of cyberspace could limit the freedom of the internet. Instead, existing international law could be applied to internet space, whereas the development of new legal regulations seems unnecessary. It should be sufficient to voluntarily submit certain principles of relations between states and to take measures that strengthen mutual trust (France Diplomacy, 2019).

The internet is a global system of interconnected computer networks whose work is not centralized. This makes the internet a global forum for freedom of expression, creating issues of responsibility and governance at the same time. As a result of the ongoing development of the information society, international organizations face a challenge of protection and support of human rights principles in an online environment. To address these issues, the Council of Europe has developed various conventions and recommendations. One such document is the Convention on Cybercrime (2001), which aims to protect the network from unauthorized and traditional crime through new technologies. An additional protocol to the Convention calls for criminal responsibility for racist and xenophobic manifestations committed via computer systems. Another important instrument is the Convention on Access to Official Documents (2008) which guarantees the right of everyone, on request, to have access to official documents held by public authorities, without discrimination on any grounds (The Council of Europe, 2019).

One of the relevant documents adopted on September 21, 2011 by the Committee of Ministers of the Council of Europe is the 10 Principles for Internet Governance. A new media vision is also offered here. These are: 1. protection of all fundamental rights and freedoms and affirmation of their universality, indivisibility, interdependence, and interrelationship; 2. ensuring full participation of governments, private sector, civil society, technical community, and users; 3 . reaffirming the responsibilities of states towards international public policy issues related to the in- 
ternet; 4. empowering internet users to exercise fundamental rights and freedoms and participate in internet governance activities; 5 . universality of the internet, recognized by the global nature of the internet and possibility of public access; 6 . integrity of the internet by means of security, stability, reliability, and resilience; 7. maintaining decentralization of responsibility for internet governance on a daily basis; 8 . preserving open standards and interoperability of the internet together with its complete nature; 9 . ensure maximum access to internet content, programs, and services; 10. maintaining cultural and linguistic diversity of the internet (The Council of Europe, 2019).

In March 2018, the Council of Europe adopted a set of recommendations that contain nearly 60 proposals for governments in terms of internet resources maintenance, such as search engines and social media, in order to support human rights and fundamental freedoms online. These recommendations cover the following topics: legality; legal certainty and transparency; guarantees of freedom of expression; safeguards for confidentiality and data protection; respect of human rights and fundamental freedoms; transparency and accountability; usage of personal data (New, 2018).

Protection and empowerment of children, which is undoubtedly a priority on the Council of Europe's agenda, has gained particular attention, alongside the challenges posed by the internet. Recommendations on empowering children in the new information and communications environment (2006) state that member states should have coherent information literacy and learning strategies that promote the empowerment of children and their educators, and improve the usage of information and communication services and technologies. The importance of promoting online learning and literacy is reiterated in another Recommendation (2009), which calls upon member states to develop and facilitate, in collaboration with representatives of the private sector and civil society, the development of strategies to protect children from content and behavior that pose a risk of harm, at the same time protecting their active participation in the new information and communication environment (The Council of Europe, 2019).

\section{Conclusions and possibilities for further research}

Thus, to date, open access to information is one of the basic principles of a democratic state and is guaranteed by the constitutions of a majority of countries. Nowadays, provision of information has become faster 
and more qualitative due to the use of the latest technologies, which has improved communication between the government and citizens. To date, a modern state is characterized by the availability of appropriate means of communication and e-governance. If properly implemented in practice, e-governance mechanisms can help a government in gaining public confidence through participatory policy. Therefore, worldwide, and in Ukraine in particular, being a member of the Council of Europe, a system of electronic education is being actively introduced, which in turn is characterized by the provision of information to the public (Shustenko, 2019, pp. 340-342).

Consequently, we have to notice that the activity of the Council of Europe today has importance as a collective body which is called on to be extremely attentive and sensitive to the attempts of the governments of the European countries to restrict the human right to information for different reasons (coronavirus, migration crisis or economic destruction). The Council of Europe significantly influences the formation and development of the system of the right to information in Europe. These rights are fixed in numerous international legal acts of the Council of Europe by means of implementation, or are fixed in the domestic law of member states of the Council of Europe in the course of their lawmaking. At the same time, the Council of Europe is criticized for inconsistency and loss of supremacy in issues that could further threaten European democracy. Just as in the situation of returning Russia to the Plenary Assembly of the Council of Europe, Tatiana Kastouéva-Jean, researcher and director of the IFRI Russia/NIS Centre, has noted that the Council of Europe gave everything away without any concessions from Russia in that matter. It sent a negative message to several other countries: the Baltic States, Poland and, of course, Ukraine (Mounier, 2019).

The human right to privacy may suffer, which is the opposite tendency to government attempts to limit information or transfer the problems of disinformation to the public sector.

We should also pay attention to the work of the relevant structures of the Council of Europe collaborating with OSCE units.

Much less criticism is aimed at the European Court of Human Rights, which is not only an important addition to national human rights mechanisms, but also, due to its decisions being considered a precedent and acknowledged as a source of law, makes a significant contribution to the exercise and protection of information rights. 


\section{Bibliography}

52 press freedom cases documented in CoE Member States during pandemic (2020), Press freedom suffers in Council of Europe member states under COVID-19, https://ipi.media/wp-content/uploads/2020/04/Briefing-Press-freedom-suffers-in-Council-of-Europe-member-states-under-COVID-19.pdf.

DW freedom (2020), CoE Commissioner for Human Rights: 'Free journalism is a crucial asset of democracy and a threat to authoritarian leaders', https://www. dw.com/en/coe-commissioner-for-human-rights-free-journalism-is-a-crucialasset-of-democracy-and-a-threat-to-authoritarian-leaders/a-53362913.

European Federation of Journalists (2020), Governments must ensure the public's right to know in the COVID-19 pandemic, https://europeanjournalists.org/ blog/2020/05/11/governments-must-ensure-the-publics-right-to-know-inthe-covid-19-pandemic/.

European Federation of Journalists (2020), Covid-19-impact on access to information in CoE countries, https://europeanjournalists.org/blog/2020/06/19/covid19-impact-on-access-to-information-in-coe-countries/.

France Diplomacy (2019), Freedom and human rights online, https://www.diplomatie.gouv.fr/ru/politique-etrangere/cifrovaya-diplomatiya/cifrovye-tehnologii-i-zadachi-v-oblasti-mezhdunarodnoj-politiki/article/svoboda-i-pravacheloveka-v-internete.

Galperovich D., Jegisman V. (2019), Freedom of speech and press in the world: trends and contrasts. Voice of America, https://www.golos-ameriki.ru/a/estonia-belarus-press-freedom/4902877.html.

Mounier J.-L. (2019), Russia's undiplomatic return to the Council of Europe. France24, https://www.france24.com/en/20190628-russia-undiplomatic-return-council-europe-ukraine.

New W. (2018), Council Of Europe Adopts Guidelines On Role Of Internet Intermediaries, Intellectual property watch, https://www.ip-watch.org/2018/03/07/ council-europe-adopts-guidelines-role-internet-intermediaries/.

Parliamentary Assembly of the Council of Europe (1970).

Resolution no. 428, Concerning the Declaration on the Media and Human Rights (In Ukrainian), https://zakon.rada.gov.ua/laws/show/994 107.

Shustenko S. O. (2019), Tools for building public confidence in the Government developed by the Council of Europe, "Hileya: naukovyi visnyk collection of scientific papers", issue no. 124, pp. 340-342 (In Ukrainian).

The Council of Europe (2019), Safeguarding human rights online, https://www.coe. int/ru/web/portal/council-of-europe-and-internet.

The Council of Europe web portal (14.10.2019).

The role of the media. Compass: Manual for Human Rights Education with Young people, https://www.coe.int/uk/web/compass/media.

Tsvik M. V., Petryshyn O. V., Avramenko L. V. et al. (2009), General Theory of State and Law, "Kharkiv: Pravo" [Law], p. 584 (In Ukrainian). 
Vienna Declaration (25 June 1993), The Verkhovna Rada of Ukraine (In Ukrainian), https://zakon.rada.gov.ua/laws/show/994 189.

Yaremenko O. (2002), Information relations as a subject of legal regulation: theoretical aspect, "Khmelnytsky University of Management and Law Visnyk journal", no. 1-2, pp. 156-161 (In Ukrainian).

\section{Działania Rady Europy w zakresie zapewniania prawa czlowieka do informacji: kwestie zgodności ze współczesnymi wyzwaniami demokracji}

\section{Streszczenie}

Autorzy artykułu dokonują przeglądu i systematyzacji działań Rady Europy w zapewnianiu jednego z kluczowych czynników demokracji liberalnej - wolności słowa, która jest warunkiem realizacji szeregu innych praw i wolności. Autorzy kategoryzują podstawowe dokumenty, zarówno te, które już stały się klasyką, jak i te przyjęte niedawno, w których zjawisko to uległo utrwaleniu prawnemu. W artykule zbadano, w jaki sposób wpływa ono na kształtowanie i rozwój prawa człowieka do informacji w Europie. Zwraca się uwagę na fakt, że wraz z pojawieniem się nowych sposobów rozpowszechniania informacji, w tym przede wszystkim wobec potencjału internetu, oraz gromadzeniem informacji i wysiłkami społeczeństw Europejskiej na rzecz ochrony tego podstawowego w demokracji prawa, jego dalsze wzmacnianie pozostaje istotną kwestią. Rada Europy utraciła kontrolę nad przestrzeganiem prawa człowieka do informacji, a informacje są wykorzystywane w destrukcyjnych celach, co stanowi zagrożenie dla jednej z fundamentalnych wartości, na podstawie których funkcjonuje dziś społeczeństwo europejskie zwiększając ryzyko przywrócenia autorytaryzmu. Autorytaryzmem zagrożone są przede wszystkim nowe demokracje Europy Wschodniej. Światowa pandemia COVID-19 i światowa recesja gospodarcza, w wyniku której obywatele chętniej wybierają autorytarnych przywódców, może być przyczyną wprowadzenia autorytaryzmu.

Słowa kluczowe: Rada Europy, prawo człowieka do informacji, media, stereotypy, dezinformacja, kontrola treści, dostęp do informacji 